\title{
Two feeding systems for lactating dairy cows grazing fertilized grasses ${ }^{1}$
}

\author{
Teodoro M. Ruiz', Benjamin Rivera ${ }^{3}$ and Norma Corchado 4
}

\begin{abstract}
Forty-eight Holstein cows were alternately assigned to one of the two following treatments: (T1) A stocking rate of 2.5 cows/ha on grass pastures fertilized with $2,270 \mathrm{~kg}(15-5-10) / \mathrm{ha} / \mathrm{yr}$, plus $1 \mathrm{~kg}$ of concentrate/2.15 kg of milk above $10 \mathrm{~kg} / \mathrm{d}$; (T2) A stocking rate of 3.125 cows/ha on pastures fertilized with $1,700 \mathrm{~kg} / \mathrm{yr}$, plus $1 \mathrm{~kg}$ of concentrate $/ 2 \mathrm{~kg}$ of milk. Through 180 days post-partum, cows in T1 produced more milk $(17.1$ vs. $14.3 \mathrm{~kg} / \mathrm{d}$; $P<0.01)$ and more $4 \%$ fat-corrected-milk (FCM; 14.8 vs. $12.9 \mathrm{~kg} / \mathrm{d} ; P<0.02$ ) than in $\mathrm{T} 2$, in spite of consuming only about half ( $3.8 \mathrm{vs} .7 .4 \mathrm{~kg} / \mathrm{d})$ as much concentrate. Body weight losses were extensive, more so for cows in T2 at both 30 (4.9 vs. $6.8 \% ; P<0.03$ ) and 90 days post-partum (6.4 vs. $9.6 \%$ of calving weight; $P<0.05)$. Feed and land costs per unit of milk produced were greater for T2 than for T1 (22.7 vs. 18.7 cents $/ \mathrm{kg}$ ). However, milk yield and income over feed and land costs per hectare grazed were greater for T2; therefore, system $\mathrm{T} 2$ represents a better alternative for intensive utilization of limited pasture resources.
\end{abstract}

Key words: lactating dairy cows, feeding systems, grasses

\section{RESUMEN}

Dos sistemas para la alimentación de vacas lecheras pastoreando gramíneas fertilizadas intensivamente

Cuarentiocho vacas Holstein en lactación se asignaron a uno de los siguientes tratamientos: (T1) Pastoreo a base de 2.5 vacas/ha en pastos fertilizados con $2,270 \mathrm{~kg}$ (15-5-10)/ha/año en cuatro aplicaciones, más $1 \mathrm{~kg}$ de concentrado/2.15 kg de leche después de los $10 \mathrm{~kg} /$ dia; (T2) Pastoreo a base de 3.125 vacas/ha en pastos abonados con $1,700 \mathrm{~kg} / \mathrm{año}$ en tres aplicaciones, más suplementación con $1 \mathrm{~kg}$ de concentrado $/ 2 \mathrm{~kg}$ de leche producida. Durante los primeros 180 días de lactación las vacas en T1 produjeron más leche (17.1 vs. $14.3 \mathrm{~kg} /$ día; $P<0.01)$ y leche corregida al $4 \%$ de grasa (14.8 vs. $12.9 \mathrm{~kg} /$ día; $P<0.02$ ) que las vacas del T2, aún cuando consumieron aproximadamente la mitad ( $3.8 \mathrm{vs} .7 .4 \mathrm{~kg} / \mathrm{día})$ del concentrado consumido por las del T2. No se observaron diferencias en el porcentaje de grasa y proteina en la leche producida. La pérdida de peso posparto fue grande y prolongada, siendo mayor a los 30 días ( 4.9 vs. $6.8 \% ; P<0.03$ ) y 90 días $(6.4$ y $9.6 \%$ del peso de parto; $P<0.05$ ) en las vacas del T2. El costo por concentrado y área de pastoreo por unidad de leche producida fue menor en el T1 (22.7 vs. 18.7 centavos $/ \mathrm{kg}$ ). Sin embargo, la producción de leche fue $23 \%$ mayor y el ingreso sobre el costo de alimento y costo del terreno $18 \%$ mayor cuando éstos se consideraron por hectárea de pasto. El sistema T2 pa-

'Manuscript submitted to Editorial Board 18 November 1993.

${ }^{2}$ Assistant Animal Husbandman, Department of Animal Industry,

${ }^{3}$ DVM, Assistant Professor, Department of Animal Industry.

${ }^{4}$ Research Associate, Central Analytical and Pesticides Laboratory. 
rece ser más adecuado para la utilización intensiva de recursos limitados de tierra para pastorear vacas lecheras.

\section{INTRODUCIIION}

Heavily fertilized tropical pastures as the only feed for dairy cows, stocked at the rate of 2.5 cows/ha, have been known to support milk productions of over $3,175 \mathrm{~kg} / \mathrm{cow}$ in the interior highlands of Puerto Rico (Caro-Costas and Vicente-Chandler, 1969; Yazman et al., 1982). At this stocking rate cows were allowed to maximize consumption of pasture dry matter (DM) and graze selectively the most nutritive parts of the grass (i.e., leaves). Under such a system, pastures received up to $2,275 \mathrm{~kg} / \mathrm{ha}$ of 15-5-10 fertilizer in four applications per year. Sotomayor et al. (1974) found that by applying annually $1,815 \mathrm{~kg}$ of fertilizer (15-5-10) per hectare, cattle harvested about $5,262 \mathrm{~kg}$ of dry forage compared with $7,348 \mathrm{~kg}$ when fertilizer level was increased to $4,535 \mathrm{~kg} / \mathrm{ha}$. Vicente-Chandler et al. (1974) reported that applying a total of $2,270 \mathrm{~kg} / \mathrm{ha}$ of $15-5-10$ fertilizer in four annual applications economically produced the highest yields of forage.

Heavily fertilized forage $(2,270 \mathrm{~kg} / \mathrm{ha} /$ year of $15-5-10)$, from pastures stocked at $2.5 \mathrm{cows} / \mathrm{ha}$, is of sufficiently high quality to support up to $15.4 \mathrm{~kg}$ of milk/day when fed to mature dairy cows (Caro-Costas and Vicente-Chandler, 1969). In vitro DM digestibilities of tropical pastures (mostly leaves) fertilized with ammonium nitrate $(350 \mathrm{~kg} / \mathrm{ha}$ ) have been reported at $70 \%$ when harvested at 30 day intervals (Moore and Mott, 1973). Under optimal climatic and nutritional conditions immature tropical forages can, in fact, achieve good digestibility. However, a pasture diet will require supplemental energy and in some cases crude protein (CP) to allow for maximum milk production (Caro-Costas et al., 1972; McDowell et al., 1975; Yazman et al., 1979; 1982). These additional nutrients can be provided by supplementing with low to moderate levels of dairy concentrates. By maintaining concentrate supplementation at a low level, extensive substitution of pasture DM will be avoided; thus, the total cost of the diet is reduced (McDowell et al., 1975).

For years the Agricultural Experiment Station (AES) has been recommending a feeding system for dairy cows based on high fertilization, low grazing pressure and low concentrate supplementation; however, these recommendations have not been implemented by dairy farmers in Puerto Rico. To maximize milk production, dairy farmers have traditionally relied heavily on imported concentrates to feed their lactating cows. Many have failed to realize the nutritive contribution of forages to the diet. Thus, the objective of this trial was to compare, in terms of milk yield and feed costs, a system typical of well managed local com- 
mercial dairy farms with a system similar to what has been recommended by the AES.

\section{MATERIALS AND METHODS}

The trial was conducted at the Gurabo Substation of the Agricultural Experiment Station, located in eastern Puerto Rico, $15 \mathrm{~km}$ from the coast and $115 \mathrm{~m}$ above sea level. Data were collected from $17 \mathrm{March}$ to 29 December 1985. Mean environmental temperature fluctuated from a daily maximum of $30^{\circ} \mathrm{C}$ to a minimum of $19^{\circ} \mathrm{C}$. Rainfall averaged $19.45 \mathrm{~cm}$ per month, with a low of 5.97 and a high of $47.60 \mathrm{~cm}$.

Forty-eight primiparous and multiparous Holstein cows were assigned alternatively, at calving, to one of the following two treatments: 1) A stocking rate of 2.5 cows/ha in pastures, fertilized with $2,270 \mathrm{~kg} /$ ha of 15-5-10 in four applications per year; plus supplementation with a commercial dairy concentrate of $16 \% \mathrm{CP}$ at a minimum level of $1.8 \mathrm{~kg} /$ $\mathrm{d} / \mathrm{cow}$ up to $10 \mathrm{~kg}$ of milk, and an additional $1 \mathrm{~kg}$ for each $2.15 \mathrm{~kg}$ of milk produced thereafter; 2) A stocking rate of 3.125 cows/ha in pastures fertilized with $1,700 \mathrm{~kg}$ of 15-5-10 analysis in three applications per year, plus $16 \% \mathrm{CP}$ concentrate offered at the rate of $1 \mathrm{~kg}$ per $2.0 \mathrm{~kg}$ of milk produced irrespective of level of production.

Pasture lots were measured before their assignment to experimental treatments. For treatment 1 (T1), six paddocks totaling 9.6 ha were rotationally grazed, according to forage availability, resulting in an average grazing interval of 30 days. Treatment 2 (T2) utilized four paddocks totaling 7.6 ha rotationally grazed, on the average, every 24 days. Botanical composition of the swards consisted of a mixture in which Cynodon nlemfuensis (star), Bracharia purpurascens (para) and Panicum maximum (guinea) were the predominant species. Throughout the trial every lot was sampled before grazing, at 15 to 20 representative locations, depending on the paddock area. Subsampling locations were randomly selected following a pattern that covered the entire area. Samples were cut at a height of 10 to $15 \mathrm{~cm}$ from the ground, depending on the type of grass predominating in the area. All samples were analyzed for CP and DM, and those taken from July to December 1985 were also analyzed for fiber fractions (Goering and Van Soest, 1970).

Data were collected during the first 180 days postpartum. Of the 48 experimental cows, 18 were primiparous and six multiparous in $\mathrm{T} 1$ and 17 primiparous and seven multiparous in T2. Calving dates of cows encompassed from 18 March to 27 June 1985. Milk weights were recorded daily for each cow. Combined am/pm milk samples were collected individually once a month and analyzed for milk fat and milk protein at the Puerto Rico Dairy Herd Improvement Association (PR DHIA) labora- 
tory. During the first 10 days postpartum, cows in both treatments received either a minimum of $9 \mathrm{~kg}$ of concentrate or their allowance as calculated above, if the latter exceeded $9 \mathrm{~kg}$ daily. Thereafter, concentrate allowances were recalculated every 10 days.

Individual reproductive records were kept throughout the experiment. Heat detection was confined to the period of cow movement before and after milking and casual observation between milkings. Health and breeding efficiency were followed closely through weekly veterinary examination and treatment as necessary. Experimental cows were weighed the day of parturition, again at the end of their calving month, and at 15 day-intervals thereafter.

Milk production data were adjusted to a mature equivalent basis with factors specific to Puerto Rico (Camoens et al., 1976). This adjustment for age and month of calving was applied to records of milk and $4 \%$ fat-corrected milk (FCM) yields. Fat corrected milk was determined by the formula $0.4 \times(\mathrm{kg}$ of milk $)+15 \times(\mathrm{kg}$ of fat $)$. After adjustments for age and month of calving, a one-way analysis of variance (Steel and Torrie, 1980) was considered appropriate for determining treatment effects. The model used to analyze the data was the following:

$$
Y_{i j}=\mu+\alpha_{i}+\beta_{i j}
$$

where $Y_{i j}=$ response variable for cow $j$ within system $i$.

$\mu=$ mean of response variable.

$\alpha_{i}=$ effect of system $i$.

$\beta_{i(j)}=$ effect of cow $j$ within system $i$, residual.

\section{RESULTS AND DISCUSSION}

\section{Forage analysis}

Crude protein contents of the available pasture forage remained relatively constant from April to September, but increased sharply from October to December (Figure 1). These findings agree with those reported by Soldevila et al. $(1979 ; 1980)$ with several grass species. Crude protein of mixed grass samples ranged from summer lows of about $8.1 \%$ to highs in fall of about $21.9 \%$ (Table 1), with levels during the summer months usually greater in T1. These data suggest that grass swards of this type differ less in percentage composition than total protein produced per unit area.

Concentration of acid detergent fiber $(\mathrm{ADF})$ and neutral detergent fiber (NDF) of pasture samples were similar between treatments (Table 1). Surprisingly, NDF concentration did not appear to change with season from July to December; however, ADF and lignin concentrations were approximately 18 and $40 \%$ lower, respectively, and hemicellulose 


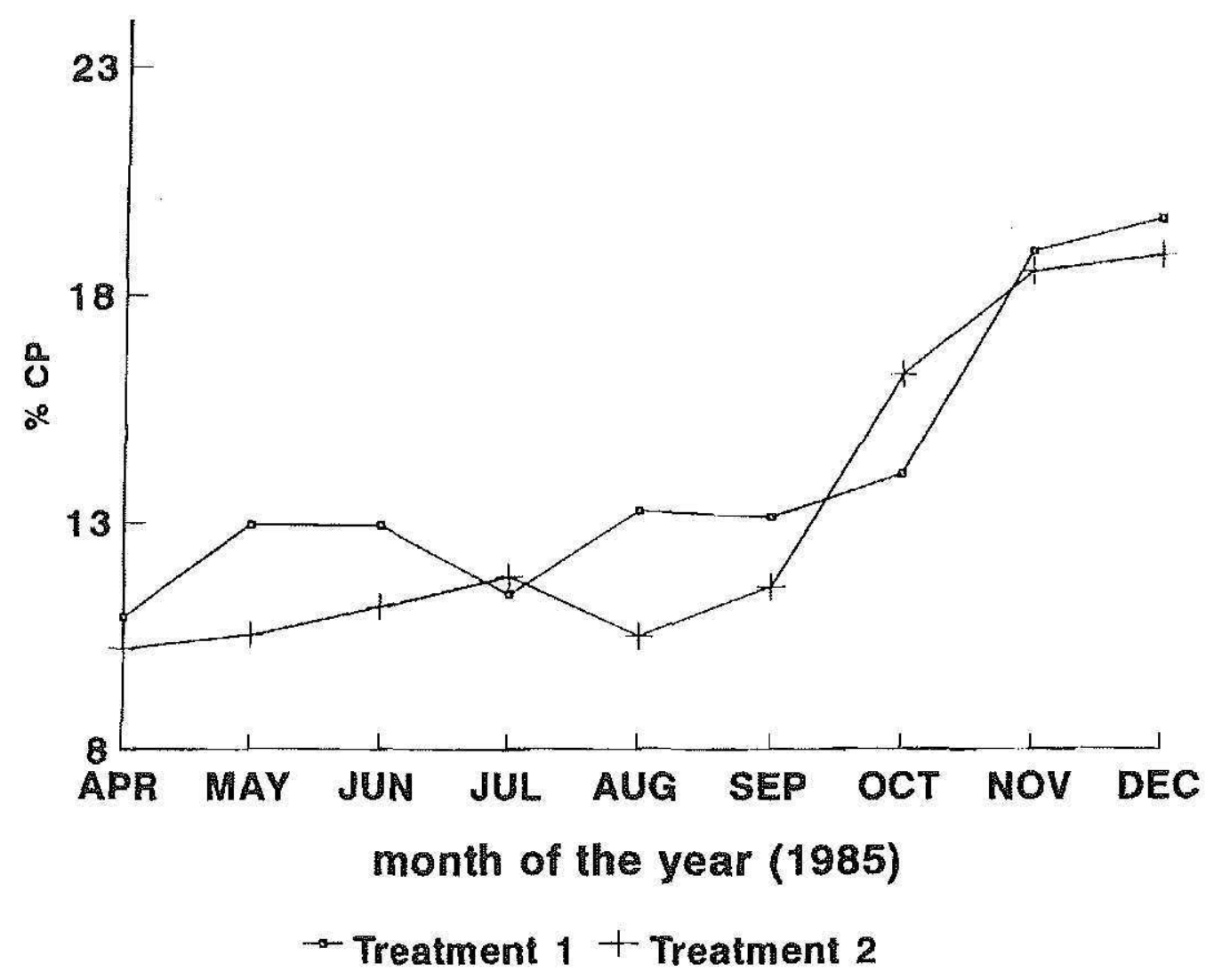

Figure 1. Crude protein concentration of forage samples collected prior to grazing.

$35 \%$ higher in December. These reductions suggest forage of higher digestibility as was indicated by an increase in predicted in vitro true digestibility (IVTD) of forage harvested in December. Since NDF fraction of forages did not change appreciably with time (69.7 in July to September vs. $70.7 \%$ in October to December), most of the increase in estimated DM digestibility can be attributed to an expected increase in digestibility of NDF.

Overall, pasture forage in $\mathrm{Tl}$ had almost $5 \%$ lower digestibility, as predicted from chemical composition of forages, despite the fact that paddocks in $\mathrm{T} 1$ received greater amounts of fertilizer. A possible explanation for this difference could be the harvest interval. Pastures in T1 were grazed, on the average, every 30 days, compared to every 24 days in $\mathrm{T} 2$.

Breeding efficiency

About one third of the experimental cows were pregnant by 180 days postpartum, $33 \%$ in $\mathrm{T} 1$ and $29.1 \%$ in $\mathrm{T} 2$; the number of services per cow by the end of the trial was 2.3 and 2.8 , respectively. Services per 
TABLE 1.-Chemical composition of mixed grass from pastures in treatment 1 (T1) and treatment 2 (T2) sampled from July to December 1985. (Percentage)

\begin{tabular}{lcccc}
\hline & \multicolumn{2}{c}{ T1 } & \multicolumn{2}{c}{ T2 } \\
\cline { 2 - 5 } & Range & Mean & Range & Mean \\
\hline Crude protein (CP) & $8.7-21.2$ & 13.5 & $8.1-21.9$ & 13.3 \\
Neutral detergent & & & & \\
$\quad$ solubles & $25.5-37.4$ & 29.2 & $25.1-38.5$ & 29.6 \\
NDF & $66.4-74.1$ & 70.3 & $66.5-74.9$ & 70.4 \\
ADF & $30.0-42.7$ & 36.6 & $28.7-44.2$ & 36.1 \\
Hemicellulose' & $20.6-42.8$ & 33.0 & $17.3-43.3$ & 34.3 \\
Cellulose' (C) & $23.3-30.7$ & 26.3 & $21.6-30.1$ & 25.9 \\
Lignin (L) & $4.8-13.4$ & 7.7 & $4.5-11.8$ & 7.2 \\
Silica (Si) & $1.3-5.2$ & 3.0 & $0.6-4.8$ & 2.0 \\
EST. IV'TD' & $50.2-75.6$ & 65.2 & $54.6-76.0$ & 69.9 \\
\hline
\end{tabular}

'Estimated by difference.

${ }^{2}$ In vitro true digestibility $=96.84+0.62(\mathrm{CP})-0.5 \mathrm{l}(\mathrm{C})-2.59(\mathrm{~L})-2.34(\mathrm{Si})$ (CowardLord et al., 1974).

conception and days open of cows pregnant by 180 days were 1.37 and 79.5 for $\mathrm{T} 1$, and 2.85 and 131.3 for T2, respectively. Days to first service were 73.7 for $\mathrm{T} 1$ and 73.3 for $\mathrm{T} 2$. In general, there was some evidence of better reproductive efficiency in $\mathrm{T} 1$. These results must be evaluated within the context of the small number of observations involved. However, the results from other studies (Caro-Costas et al., 1972; McDowell) et al., 1975; Yazman et al., 1979; 1982) have also suggested that cows grazed at high stocking rates and heavily supplemented with concentrates under similar management conditions, required more services per conception, remained open longer and had longer calving intervals than cows grazed at low stocking rates and fed lower amounts of concentrates.

\section{Milk production}

During the first 180 days of lactation, cows in $\mathrm{T} 1$ produced over $19 \%$ more milk $(\mathrm{P}<0.01)$ and almost $14 \%$ more FCM $(\mathrm{P}<0.03)$ than those in T2 (Table 2). Approximately $56 \%$ of the difference in total corrected milk yield between treatments was accounted for by day 60 of lactation (Figure 2). Peak daily milk production was 21.9 and $20.6 \mathrm{~kg} / \mathrm{d}$ for cows in T1 and T2, respectively. Milk production peaked after a mean postpartum interval of 30 days in both treatments. Later peaks, between 30 and 50 days postpartum, were observed by Yazman et al. $(1979 ; 1982)$. 
TABLE 2--Least-square means for milk and FCM production, adjusted' for age and month of calving, and milk composition of cows in treatment 1 (T1) and treatment 2 (T2) through 180 days postpartum.

\begin{tabular}{lccc}
\hline & T1 & T2 & se \\
\hline Milk Production' & & & \\
Mean $(\mathrm{kg} / \mathrm{d})$ & 17.1 & 13.4 & 0.57 \\
Total $(\mathrm{kg})$ & 3087 & 2582 & 103.3 \\
Fat corrected milk & & & \\
$\quad$ Mean $(\mathrm{kg} / \mathrm{d})$ & 14.8 & 12.9 & 0.55 \\
Total $(\mathrm{kg})$ & 2672 & 2319 & 99.3 \\
Milk fat $(\%)$ & 3.28 & 3.24 & 0.06 \\
Milk protein $(\%)$ & 2.92 & 2.98 & 0.03 \\
Partial feed efficiencyz. & 4.29 & 1.73 & 0.14 \\
\hline
\end{tabular}

${ }^{1}$ Camoens et al., 1976.

'Mean of $\mathrm{T} 1>\mathrm{T} 2(\mathrm{P}<0.01)$.

"Mean of $\mathrm{T} 1>\mathrm{T} 2(\mathrm{P}<0.02)$.

${ }^{4} \mathrm{E}$ fficiency $=\mathrm{kg}$ of $\mathrm{FCM} / \mathrm{kg}$ of concentrate.

The results in this study differ from those of Yazman et al. (1979; 1982), who reported that supplementation of concentrate, at the rate of $1 \mathrm{~kg}$ per $2 \mathrm{~kg}$ of milk, increased production over that obtained with supplementation after the $10^{\mathrm{hh}} \mathrm{kg}$ of milk. Caro-Costas and VicenteChandler (1969) studied effects of concentrate supplementation at the rates of $1 \mathrm{~kg}$ per $2.15,4.30,6.45$ and $8.60 \mathrm{~kg}$ of milk produced, using a stocking rate of 2.5 cows per hectare of pasture fertilized with $2,270 \mathrm{~kg}$ of $15-5-10 / \mathrm{ha} / \mathrm{yr}$. These authors reported greater milk production at the three highest levels of concentrate supplementation; even though milk production was similar, there was a large difference in amounts of concentrate fed among the three levels. Similarly, in the present trial, cows in $\mathrm{T} 1$ produced more milk in spite of consuming only about half as much concentrate ( 3.8 vs. $7.4 \mathrm{~kg} / \mathrm{d}$ ) as those in T2. Presumably cows in T1, which grazed a greater area of pasture fertilized at a higher level, consumed substantially more pasture DM to compensate for lower concentrate intake. As a result of lower intake of concentrate and higher milk yield, cows in T1 had greater $(\mathrm{P}<0.01)$ efficiency of concentrate utilization for production of FCM (Table 2).

Production of dairy cows in this trial can be considered low for cows in their first 180 days of lactation. However, environmental stress (temperature, humidity and solar energy) has a negative effect on intake of forage DM in cows grazing tropical pastures. Wayman et al. (1962), have reported that dairy cows exposed to ambient temperatures above $27^{\circ} \mathrm{C}$ for more than six hours reduced total DMI by $12 \%$, whereas at $30^{\circ} \mathrm{C}$ the reduction can be as high as $50 \%$. In addition, during heat 


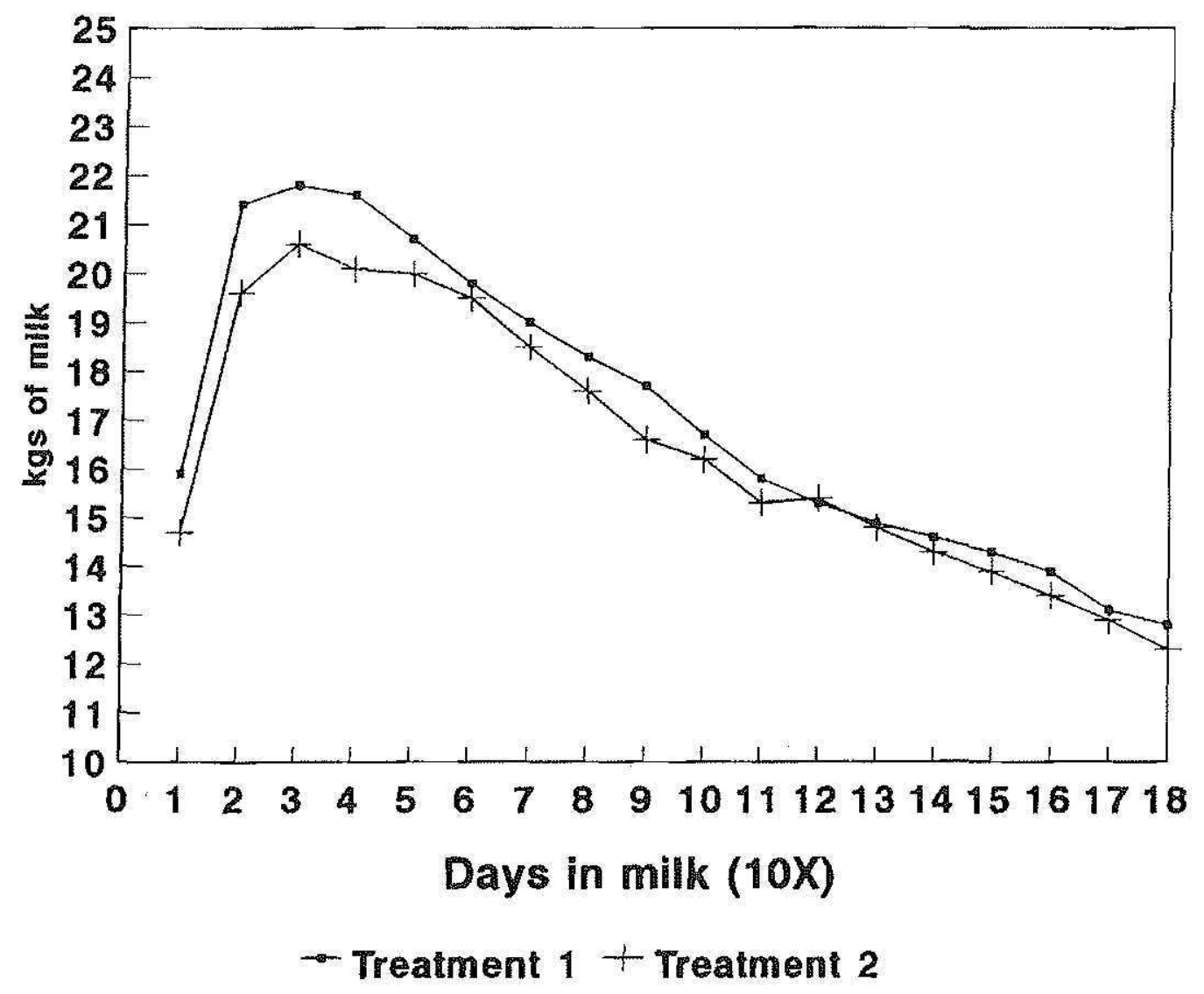

FIGURE 2. Average 10-day milk production of experimental cows during the first 180 days of lactation of each cow, and based on actual milk corrected for age and month of calving.

stress the efficiency of utilization of dietary energy for milk energy can be reduced 30 to $50 \%$ (McDowell, 1985). During this trial the net effect on forage intake of the management employed, in both treatments, was negative.

No significant difference was detected between treatments in percentage milk fat or milk protein (Table 2). Both treatments appeared to have supplied adequate amounts of ruminally effective fiber to maintain milk fat percentage at the levels typical of this herd. These results are consistent with those of Yazman et al. (1979; 1982), who showed that milk fat was maintained at a normal level in spite of higher concentrate supplementation when enough quality forage was supplied in the diet.

Body weight (BW) change

At calving, cows in T1 and T2 averaged 463.4 and $491.5 \mathrm{~kg} \mathrm{BW}$, respectively. Cows in both systems lost weight during the first 30 days 
postpartum (Table 3). Although cows in T2 remained heavier than those in $\mathrm{T} 1$ throughout the trial, $\mathrm{BW}$ loss at 30 days postpartum was greater $(\mathrm{P}<0.03)$ for cows in T2 $(6.8$ vs. $4.9 \%$ of calving weight). From 30 to $60 \mathrm{~d}$ postpartum and from 60 to $90 \mathrm{~d}$, weight losses in both treatments were minimal. However, at $90 \mathrm{~d}$ postpartum total body weight loss was greater for cows in T2 6.4 vs. $9.6 \%$ of calving weight; $\mathrm{P}<0.05$ ). On average, cows in $\mathrm{T} 2$ were not gaining weight by $180 \mathrm{~d}$ postpartum and those in T1 began gaining weight only after 165 days.

It is recommended that in order to maximize milk yield and improve reproductive efficiency, the length of the period of weight loss during early lactation should be minimized (Moe et al., 1971). In the present study the period of weight loss was much longer than optimal (National Research Council, 1978). Most of the cows appeared to have been in negative energy balance for at least 100 days postpartum and were still not gaining weight by 180 days postpartum. Visual observation of the body condition of experimental cows substantiated this fact.

Since all of the pelleted concentrate offered was consumed, it seems reasonable to assume that failure to regain BW was largely due to insufficient DMI from grass to meet requirements, that maintenance requirements were increased by the long walks to the distant paddocks, or both. Thus, under conditions of stress, such as those in the present trial, grazing does not maximize DMI. The possibility that other forage feeding systems could improve DMI over that obtained with grazing should be investigated.

Economic analysis

Cows in T1 seemed to adjust better during early lactation, in terms of BW loss and milk production, despite receiving substantially lower

TABLE 3,-Least square means of body weight (BW) changes of cows as affected by experimental treatments during the first 90 days postpartum.

\begin{tabular}{|c|c|c|c|}
\hline & $\mathrm{T} 1$ & $\mathrm{~T} 2$ & se \\
\hline & \multicolumn{3}{|c|}{$\ldots \ldots \ldots$} \\
\hline BW loss at 30 d postpartum ${ }^{1}$ & 22.7 & 37.7 & 4.4 \\
\hline BW loss from 30 to $60 \mathrm{~d}$ postpartum & 3.5 & 3.4 & 4.0 \\
\hline BW loss at $60 \mathrm{~d}$ postpartum & 26.3 & 41.1 & 5.4 \\
\hline BW loss from 60 to $90 \mathrm{~d}$ postpartum & 3.5 & 6.1 & 3.2 \\
\hline BW loss at 90 d postpartum ${ }^{2}$ & 29.8 & 47.2 & 6.0 \\
\hline
\end{tabular}

Mean of $\mathrm{T} 1<\mathrm{T} 2(\mathrm{P}<0.03)$.

Mean of $\mathrm{T} 1<\mathrm{T} 2(\mathrm{P}<0.05)$. 
levels of concentrate supplementation. Furthermore, considering the high cost of imported dairy concentrates, the large difference in concentrate consumption would prima facie make $\mathrm{T} 1$ seem economically more desirable. However, other factors must be considered. At the time of this trial (1985), the price for fertilizer (15-5-10) was $\$ 204 / \mathrm{m}$ ton and for a $16 \% \mathrm{CP}$ commercial concentrate was $\$ 27.54 / 100 \mathrm{~kg}$. The cost of maintaining and operating a tractor to fertilize and mow the pastures was calculated on the basis of rental fee or approximately $\$ 15$ per hour. Costs assigned to land under grazing were calculated as 10\% (assumed interest rate) of the market value of the land $(\$ 7,500 / \mathrm{ha})$. The average price received for milk sold during the experiment was $\$ 0.50$ per $\mathrm{kg}$.

At these prices, income over feed and land cost was $\$ 0.76 /$ cow $/ \mathrm{d}$ higher for T1 (Table 4). Cows in T1 produced $\$ 136.80 /$ cow more milk income over feed and land cost than cows in T2 during the first 180 days of lactation. The economic data also suggested a higher cost per unit of milk produced in T2 (22.7 vs. 18.1 cents/kg millk).

However, when considering milk production per unit of pasture land area utilized for grazing, T2 cows produced $23 \%$ more milk per ha than cows in T1 (Table 5). This translates into $\$ 378.00$ more income after feed and land costs over the first 180 days of lactation per hectare of land grazed. If we consider that in Puerto Rico the average dairy farmer utilizes approximately 0.4 ha of pasture land per milking cow, and the limiting factor for expansion on most farms is lack of land, T2 seems a more efficient system, in economic terms, for local farmers. A system similar to T2 seems better suited for intensive utilization of limited pasture resources of the typical dairy farm in Puerto Rico.

TABLE 4.-Estimated income over feed and land costs for treatment 1 (T1) and treatment 2 (T2), calculated on the basis of cow per day.

\begin{tabular}{|c|c|c|c|}
\hline & & $\mathrm{T} 1$ & $\mathrm{~T} 2$ \\
\hline & & \multicolumn{2}{|c|}{ - . - - dollars/cow/d - . . . . } \\
\hline Gross income 1 & & 7.36 & 7.24 \\
\hline Concentrate feed cost & . & 1.04 & 2.03 \\
\hline Pasture maintenance and fertilization ${ }^{2}$ & & 0.29 & 0.24 \\
\hline Fertilizer cost & & 0.51 & 0.38 \\
\hline Land cost ${ }^{3}$ & & 0.82 & 0.65 \\
\hline Income over feed and land costs & & 4.70 & 3.94 \\
\hline
\end{tabular}

${ }^{1}$ Based on income from actual millk production.

${ }^{2}$ Based on $3 \mathrm{~h}$ of tractor use $(\$ 15.00 / \mathrm{h})$ for clipping and $50 \mathrm{~min}$ for fertilization of a hectare of land.

${ }^{3}$ Assuming market value of an hectare of land is $\$ 7,500$, and based on a $10 \%$ interest rate. 
TABLE 5.-Estimated income over feed and land costs for treatment 1 (T1) and treatment 2 (T2), based on income per hectare of pasture.

\begin{tabular}{lcc}
\hline & T1 & T2 \\
\hline & $\ldots \ldots$ dollars/ha/d $\ldots \ldots$ \\
Milk production ${ }^{\mathrm{i}}(\mathrm{kg} / \mathrm{ha} / \mathrm{d})$ & 36.70 & 45.20 \\
Value of milk produced & 18.40 & 22.62 \\
Concentrate cost & 2.60 & 5.07 \\
Pasture maintenance and fertilization cost & 0.75 & 0.72 \\
Fertilizer cost & 1.27 & 0.95 \\
Land cost & 2.05 & 2.05 \\
Income over land and feed costs & 11.73 & 13.83
\end{tabular}

${ }^{1}$ Actual milk production.

\section{LITERATURE CITED}

Camoens, J. K., R. E. McDowell, L. D. Van Vleck, M. Drosdoff, P. O. Miller, G. R. Ufford and J. D. Rivera-Anaya, 1976. Factores para ajustar los registros de producción de vacas Holstein en P.R., según la edad del animal y mes de nacimiento. Esta. Exp. Agric. Univ. P.R., Publ. 99.

Caro-Costas, R., J. Vicente-Chandler and F. Abruña, 1972. Effect of four levels of concentrate feeding on millk production by Holstein cows grazing intensively managed tropical grass pastures. J. Agric. Univ. P.R. 56(4):97-104.

Caro-Costas, R. and J. Vicente-Chandler, 1969. Mill production with all-grass ration from steep, intensively managed tropical pastures. J. Agric. Univ. P.R. 58(3):251-58.

Coward-Lord, J., J. A. Arroyo-Aguilú and O. García-Molinari, 1974. Fibrous carbohydrate fractions and in vitro true and apparent digestibility of 10 tropical forage grasses. J. Agric. Univ. P.R. 58(3):293-304.

Goering, H. K. and P. J. Van Soest, 1970. Forage fiber analyses (apparatus, reagents, procedures and some applications). Agric. Res. Sexv́, USDA Agric. Handbook No. 379.

McDowell, L. R., 1985. Nutrition of Grazing Ruminants in Warm Climates. Academic Press Inc., Orlando, Florida.

McDowell, R. E., H. Cestero, J. D. Rivera-Anaya, F. Román-García, J. A. Arroyo-Aguilú, J. A. Berrocal, C. M. Soldevila, J. C. López-Alberty and S. W. Metz, 1975. Tropical grass pastures with and without supplement for lactating cows in P.R. Agric. Exp. Sta. Univ. P.R. Bull. 238.

Moe, P. W., H. F. Tyrrell and W. P. Flatt, 1971. Energetics of body tissue mobilization, $J$. Dairy Sci. 54(4):548-53.

Moore, J. E. and G. O. Mott, 1973. Structural inhibitors of quality in tropical grasses. Pages 53-98 In: Antiquality Components of Forages, A. G. Matches, ed., CSSA Special Publ. 4, Crop Science Society of America, Madison, WI.

National Research Council, 1978. Nutrient Requirements of Dairy Cattle, 5th rev, ed. Washington, D.C.; National Academy of Sciences.

Soldevila, M., 1980. Effect of rotation length in pangola pastures upon the liveweight gain in growing Holstein heifers. J. Agric. Univ. P.R. 64(2):243-46.

Soldevila, M., J. Green-Ortiz, A. Sotomayor-Ríos, J. A. Arroyo-Aguilú and J. Vélez-Santiago, 1979. Alimentación de novillas Holstein a base exclusiva de pastos taner, 
pangola común y milanjiana, guinea y signal cultivados adecuadamente durante las cuatro estaciones del año. Agric. Exp. Sta. Univ. P.R. Publ. 127.

Sotomayor-Ríos, A., F. J. Julia and J. A. Arroyo-Aguilú, 1974. Effect of harvest interval on the yield and composition of 10 forage grasses. J. Agric. Univ. P.R. 58(4):448-55.

Steel, R. G. D. and J. H. Torrie, 1980. Principles and procedures of statistics; a biometrical approach. 2nd ed., McGraw-Hill Book Company, New York, NY.

Vicente-Chandler, J., F. Abruña, R. Caro-Costas, J. Pigarella, S. Silva and R. W. Pearson, 1974. Intensive grassland management in the humid tropics of Puerto Rico. Univ. P.R. Agric. Exp. Sta. Bull, 233.

Wayman, O., H. D. Johnson, C. P. Merilan and I. L. Berry, 1962. Effect of ad libitum or force-feeding of two rations on lactating dairy cows subject to temperature stress. Missouri Agric. Exp. Sta. J. No. 2495:1472-77.

Yazman, J. A., R. E. McDowell, H. Cestero, J. A. Arroyo-Aguilú, J. D. Rivera-Anaya, M. Soldevila and F. Román-García, 1982. Efficiency of utilization of tropical grass pastures by lactating cows with and without supplement. J. Agric. Univ. P.R. 66(3):200-22.

Yazman, J. A., R. E. McDowell, H. Cestero, E. Román-García and J. A. Arroyo-Aguilú, 1979. Supplementation of dairy cows grazing intensively managed tropical grass pastures at two stocking rates. J. Agric. Univ. P.R. 63(3):281-93. 